\title{
Roche faces charges over Taq patent claim
}

Munich. Swiss pharmaceuticals company Hoffmann-La Roche and US biotechnology company Cetus face charges of intent to mislead the US Patent and Trademark Office (PTO) in their claims to native Taq DNA polymerase, the key enzyme in the polymerase chain reaction (PCR).

A federal court ruled last week that Cetus - the company originally granted the patent in 1989 - acted with "gross negligence" in withholding relevant information from the PTO. The court has set a hearing for next month to discuss whether the company acted with intent to mislead, and to fix a date for a trial. If intent is proved, the patent would be declared unenforceable.

Hoffmann-La Roche bought the patent rights for native Taq, along with a bundle of related patents, including recombinant $T a q$ polymerase and the PCR methodology itself, for US\$300 million in 1991. The longrunning court case began four years ago when Roche sued Promega, a US laboratory supply company, for patent infringement. Promega had refused to sign a new licensing agreement that would have increased its royalty payments fivefold.

Promega shifted the focus of the case by counterclaiming that the patent on native Taq polymerase should be declared invalid. It also called for Roche's other PCR-related patents to be declared invalid. The key issue in Promega's arguments is whether the enzyme extracted from the bacterium Thermus aquaticus described in the Cetus patent is the same as that extracted by scientists from the University of Cincinnati in 1976 and by a Russian group in 1980 (see Nature 373, 377; 1995)

Cetus argued that its enzyme was different, and therefore patentable. This issue is widely contested. Only last month the European Patent Office rejected a patent application from Roche for native Taq because it believed the enzymes to be the same (see Nature 381, 100; 1996).

Promega presented to the US court more than a dozen pieces of evidence to support its contention that Cetus had supported its patent claim with arguments that were inconsistent with well-known scientific principles, or that Cetus had withheld relevant

\section{Free speech a thing of the past?}

London. British universities are considering charging journalists on national newspapers for interviews with academics. The suggestion comes from the Committee of Vice-Chancellors and Principals (CVCP) in retaliation for a plan by newspapers to levy a $£ 0.02$ royalty (US $\$ 0.03$ ) on every article photocopied in a university.

The CVCP's proposal has provoked a mixture of outrage and bewilderment among scientists and journalists. "I find the idea pretty horrifying," says Esther Pocock, a spokeswoman for the Biotech-

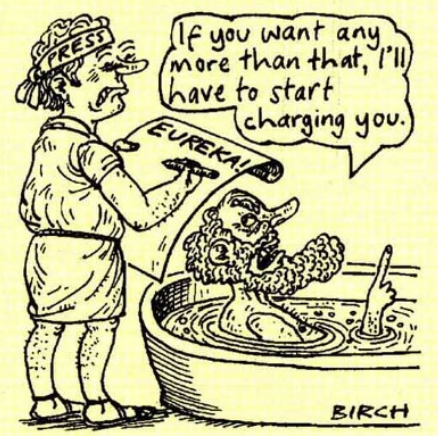

is not losing sleep, however: “I don't think it'll ever see the light of day. I can't see any publication approaching any scientist who is going to charge."

Steve Jones, professor of genetics at University College London and a regular nology and Biological Sciences Research Council. "Scientists have a duty to explain to the public what they are doing", she says, adding that that is an obligation written into research grants.

Pocock says that the introduction of fees would also diminish the quality of science reporting, explaining that scientists "must be willing to give advice freely" if they want to be reported accurately. Scientists may also be loath to bite the hand that feeds them; they need the media as much as the media need them.

Nigel Hawkes, science editor of The Times, thinks the idea of fees is "crude, totally unenforceable and ill-advised". He newspaper columnist who has also written and broadcast radio and television programmes, says the proposal is "obviously wrong". "Unless I am mistaken, universities are supposed to be in the business of disseminating knowledge."

Both universities and institutions such as the Natural History Museum in London charge commercial clients for science advice. But enquiries from the public and journalists are "always free of charge", says Gina Dobson, a spokeswoman for the museum.

Whether the universities seriously intend to put an end to this practice remains to be seen. Graham Zellick who is vice-chancellor-elect of the University of London, and represents CVCP in discussions on copyright with the Newspaper Licensing Agency, a body representing most of Britain's national dailies - was away on holiday as Nature went to press. information contained in its own laboratory notebooks. The court upheld five of Promega's claims.

The court agreed, for example, that Cetus had misrepresented scientific principles by claiming that the enzyme was unique because its apparent molecular weight was significantly higher than estimates reported earlier in the literature. Cetus had argued that this difference could not be accounted for by differences in methodology.

Cetus had claimed that the method of estimation of molecular weight used by the Cincinnati group - gel filtration chromatography, a sizing technique - was reliable, so the $20 \mathrm{kDa}$ difference in molecular weight observed reflected true differences in the enzyme proteins purified.

But internal Cetus documents showed that the company knew that the method yielded unreliable estimates of molecular weight and the court ruled that Cetus had withheld relevant information.

Cetus had further claimed that, even if the enzymes were the same, the protein of lower molecular weight described by the Cincinnati group could not be the full-length enzyme but a smaller proteolytic breakdown product. Yet laboratory notebooks showed that Cetus had carried out experiments with a proteolytic fragment of Taq of the appropriate molecular weight. The fragment did not bind to the chromatography column used by the Cincinnati scientists to purify the enzyme.

In its defence, Roche says that binding is notoriously dependent on experimental conditions, and that even small differences could have explained the failure of the fragment to bind. Nonetheless, the court said that the company should have supplied the information, as it would have helped the PTO to assess Cetus's original patent claim.

The court dismissed Roche's claim that its enzyme was much purer than those previously extracted and that this alone justified its patent, arguing that the company had exaggerated the purity of its preparation. Roche says the judge miscalculated the purity value.

Tom White, head of Roche's US West Coast research and development department, is confident that the company will successfully defend itself against all the other charges, and prove there was no intent to mislead.

Promega is equally confident. "There have been so many instances of obvious misrepresentation that they can't be considered a series of mistakes," says Randall Dimond, chief technical officer at Promega. Even if Roche wins this case, he says, it is unlikely to win the next stage, which will be a trial to consider the validity of the patent, given the current ruling of gross misconduct. 